\title{
Novartis School Lab: Bringing Young People Closer to the World of Research and Discovering the Excitement of Science
}

\author{
Christiane Röckl Michel, Gesche Standke, and Reto Naef*
}

\begin{abstract}
The Novartis School Lab (http://www.novartis.ch/schullabor) is an institution with an old tradition. The School Lab reaches about 5000 students through internal courses and an additional 5000 children at public science events where they can enjoy hands-on science in disciplines of biomedical research. The subjects range from chemistry, physics, molecular biology and genetics to toxicology and medical topics. The Novartis School Lab offers a variety of activities for youngsters aged 10-20 ranging from lab courses for school classes, continuing education for teachers and development of teaching kits, support for individual research projects to outreach for public science events. Innovation and adaptation to changes of current needs are essential aspects for the Novartis School Lab. Ongoing activities to shape the Novartis Biomedical Learning Lab include design of new teaching experiments, exploration into additional disciplines of biomedical science and the creation of a fascinating School Lab of the future.
\end{abstract}

Keywords: Gen-Spirale · Hands-on science · Novartis School Lab · Science education

\section{Sustainable Talent Promotion Starts Early}

Young people have the idea that a scientist's life means long working hours, enduring endless frustrations, vigorous competition and only a few make it to the top. Although this is true, isn't there so much more? The excitement of discovery, a welldeveloped curiosity and the will to succeed are attributes most scientists will state as fundamental for their scientific career.

The Novartis School Lab (http://www. novartis.ch/schullabor) gives young people the opportunity to do experiments on their own and to discover the excitement of expecting individual results. Combining the careful work of the young experimenters with the experience of the coaching School Lab team and a successful outcome is highly likely.
As an out-of-school education center the Novartis School Lab encourages science teaching. There is a broad spectrum of activities: lab courses for school classes, individual research projects, practical workshops and teaching kits for teachers. Thus the School Lab supports not only Novartis as such but also the Swiss educational system. Since "human resources in science and technology are vital resources for economic growth and the development of knowledge-based economies and societies" (Swiss Federal Statistical Office 2005) there is a strong public interest in career building in science and technology. Swiss universities and technical colleges are known for their superior training. However, too few young people choose a professional career in natural sciences. Meanwhile the research-based industry is confronted with a shortage of scientifically trained talents.

Good biomedical research is only possible with talented and motivated employees. As a leading healthcare company, it is the mission of Novartis to develop new and innovative medicines and to provide better therapies to patients. Sustainable talent promotion at Novartis does not only mean offering professional and personal development training to associates, but also includes activities for children and young people. One example of this commitment is the onsite Novartis School Lab. Novartis associates enjoy a dialogue with students of various ages where they not only trans- fer their own knowledge but also benefit from exchanges with the younger generation.

A schoolgirl from Bern, who is being treated with a Novartis medicine, recently approached the company. As part of her final school project, she requested help on the synthesis of the drug substance and information on how the medicine works. A request the Novartis School Lab was more than happy to fulfill.

\section{The Novartis School Lab: An Institution with an Old Tradition and a Young Vision}

On August 16, 1993 the Ciba School Lab was inaugurated in the presence of prominent representatives from the Basel government and board members of the Novartis predecessor company. The concept of the School Lab was focused on the promotion of interest and enthusiasm in natural science for children 10-15 years old. The School Lab, founded at a time when Europe was in the middle of an economic recession, was designed to be a partnership between public schools and industry from its inception.

More than 170 school classes visit the Novartis School Lab and together with our activities on public science events, every year about 10'000 students get their first lab-based exposure to natural science through this institution. 


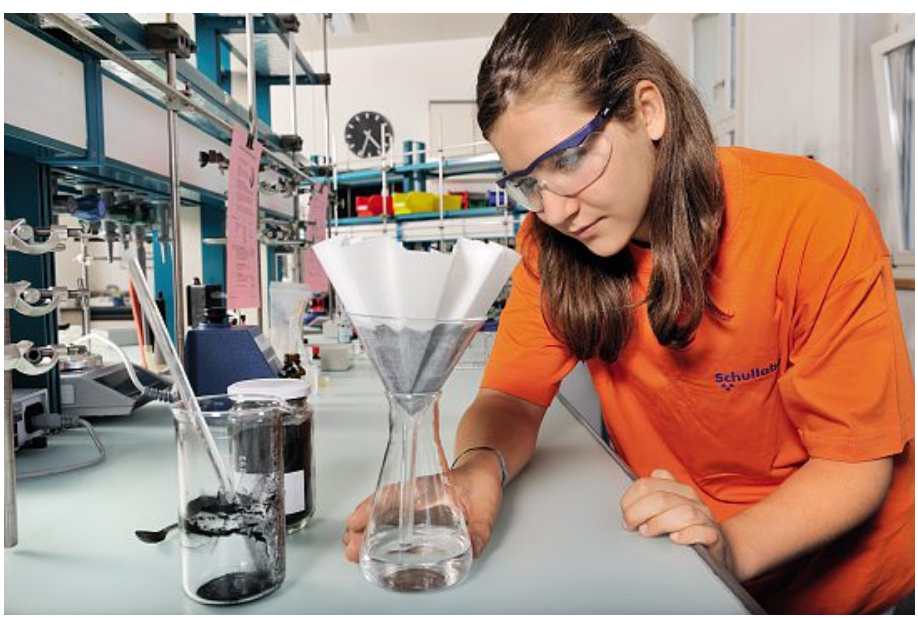

Fig. 1. Example of the chemistry program for class level 8-10. Cola is discolored using activated carbon.

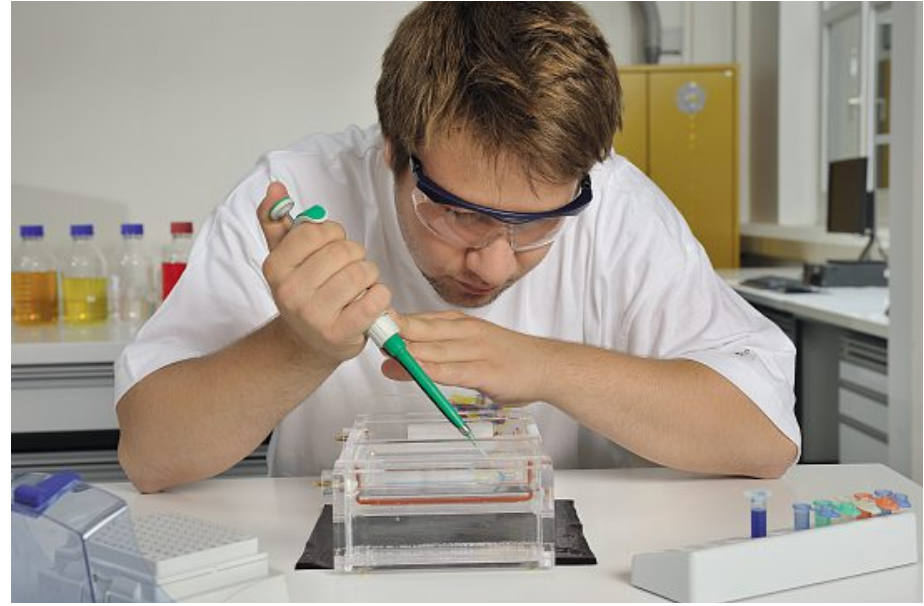

Fig. 2. Example of the genetic program for class level 11-13. DNA fragments are separated and visualized by gel-electrophoresis.
Initially the Ciba School Lab focused on chemistry and physics, at the time when the students didn't have chemistry and physics lessons in school. This introductory exposure to hands-on science was especially welcome in times when public schools had very limited budgets for lab installations.

The Novartis School Lab has always adapted to current needs and is undergoing a major transformation process in many aspects. Molecular biology lab courses for high school students were implemented 1997. Soon after the success of this course, the teaching kit 'Gen-Spirale' for high schools was developed and launched in 1998.

To add to our existing teachers' expertise in chemistry, biochemistry, molecular biology and genetics we were recently able to hire several $\mathrm{PhD}$ students from the University of Basel, who nicely complement the existing knowledge base. Through the broadened pool of teachers we manage the transformation of the School Lab into a multidisciplinary biomedical learning lab, develop new experiments and teaching tools and offer teacher courses and support individual research programs. With our diversified lab-based science programs we reach talented youngsters between ten to twenty years of age.

19 years after the birth of the Novartis School Lab the out-of-school education center is well established and recognized. New directions for the Novartis School Lab have been identified and will be implemented over the coming years. Some of the transformation elements for the Novartis School Lab in the coming years include broadening the covered disciplines in bio- medical sciences together with implementation of computational science elements and the creation of a new modern learning lab.

\section{Laboratory Courses for School Classes}

Although hands-on experiments are proven to be perfect tools to teach scientific principles, their implementation in the classroom is not always easy. Equipment and chemicals are required and must be elaborately prepared. Schools that do not have the necessary infrastructure have the possibility to perform experiments in the well-equipped Novartis School Lab. For various biomedical topics, courses are offered with experiments ranging from easy to challenging (Figs 1 and 2). Up to 24 students can participate in courses lasting 3 to 6 hours, according to the program chosen.

The range of topics is suitable for class levels 8 to 13 . A popular program for younger high school students, which has been used since the inception of the Ciba School Lab, is Caro's indigo synthesis and its use as a blue dye. The young people are usually surprised when they realize how much chemistry is applied to their favorite jeans. They follow the instructions carefully and compete with each other for who can create the most beautiful shade of blue. At the same time, they learn the concepts of reduction and oxidation, and observe that even minor modifications in the molecular structure can greatly change the properties of a substance (such as solubility and color) (Scheme 1).

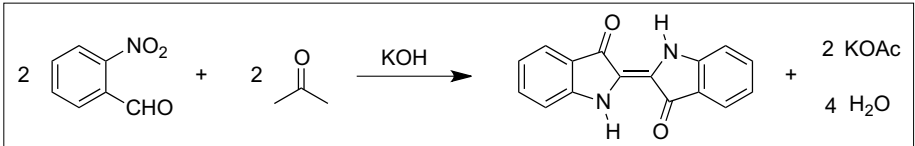

An advanced program for older students introduces the important method of SNP genotyping by analyzing the gene of a bitter taste receptor. Different variants, i.e. alleles, of this receptor gene are equally distributed in the human population. The investigated gene variants differ only in one nucleotide. This single nucleotide polymorphism (SNP) changes the receptors sensitivity. Using molecular biological methods such as polymerase chain reaction and restriction fragment length polymorphism the students identify their own genotype (Fig. 3). In a simple taste test, they determine also their phenotype and compare it with the previously classified genotype. Class results show how well the bitter tasting actually conforms to classical Mendelian inheritance, and illustrate the modern concept of pharmacogenetics where a SNP genotype is used to predict drug response.

\section{Individual Research Projects}

In addition to the class lab, two smaller laboratories have recently been established. These facilities are open to young researchers who wish to perform individual experimental projects, such as the Swiss high school thesis (Maturaarbeiten). In close collaboration with the teachers, the School Lab team is happy to give the

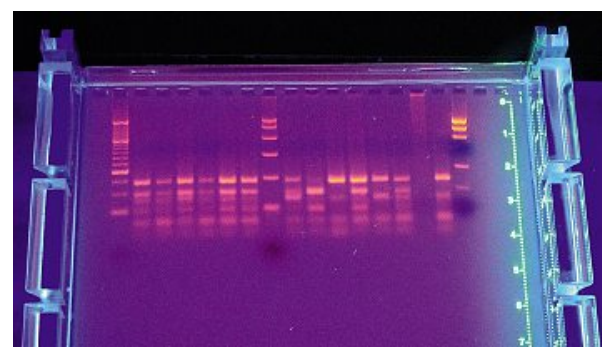

Fig. 3. SNP genotyping of a bitter taste receptor gene. A typical class result is shown. 


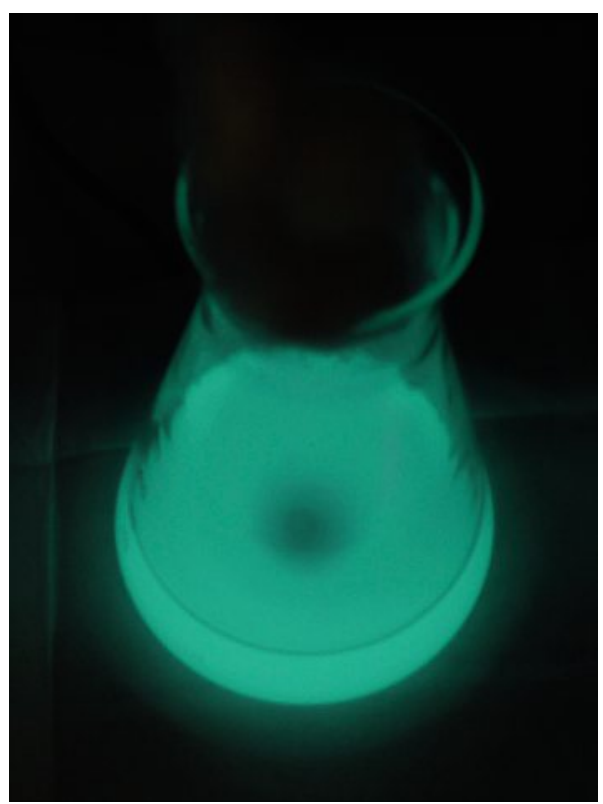

Fig. 4. Liquid culture of the luminescent bacteria Vibrio fischeri.

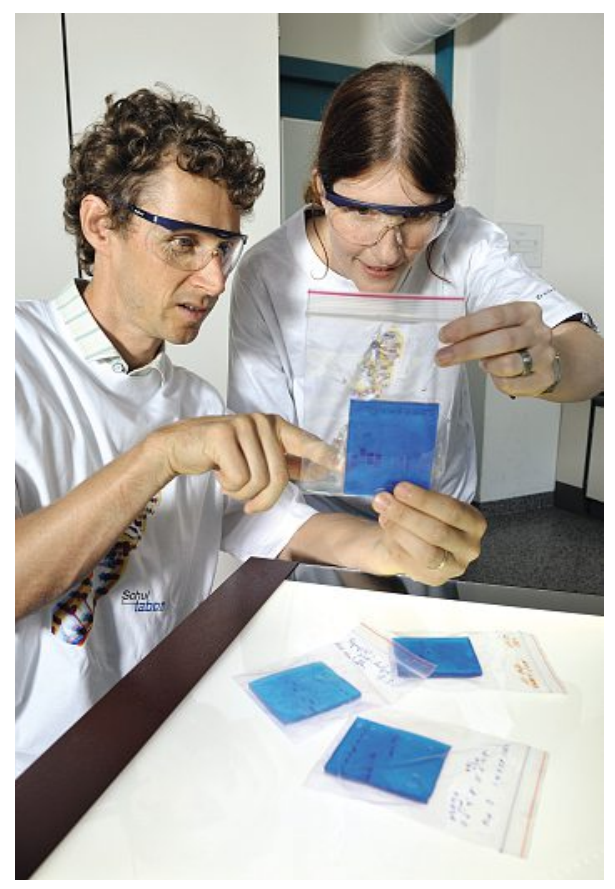

Fig. 6. Participants of the teacher workshop on UV-light and DNA. Exposure to UV-light changes DNA structure. The structural modifications lead to an altered migration velocity in gel-electrophoresis.

young scientists practical assistance and advice. This summer a student worked with the marine luminescent bacteria Vibrio fischeri, a strain that is usually used as a model organism to measure water quality (Fig. 4). If a substance is toxic, the metabolism of the bacteria cells is affected and the luminescence decreases. In her Maturaarbeit, the student investigated how the luminescence of the bacteria was changed after adding common painkillers. She could show that the effect depends on the concentration and on the nature of the substance (Fig. 5).

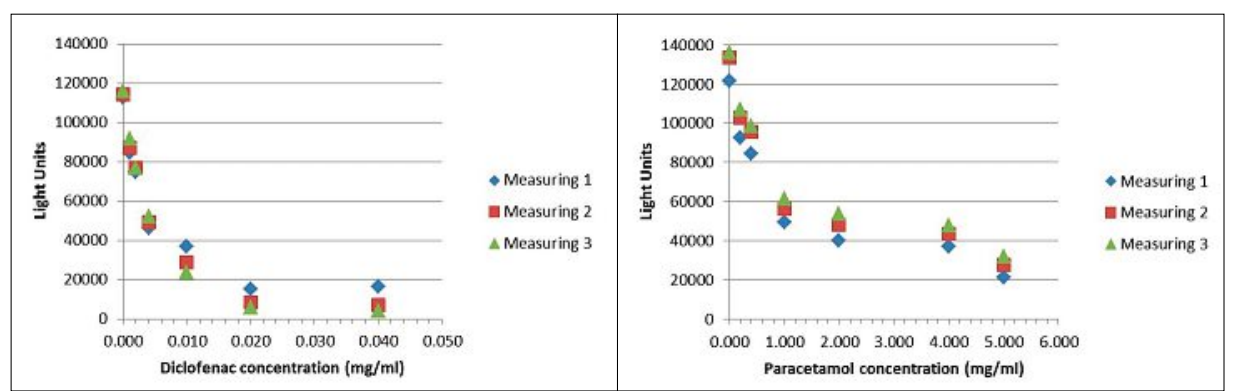

Fig. 5. Effect of painkillers Diclofenac and Paracetamol on the luminescence of a Vibrio fischeri culture. Even at low Diclofenac concentrations the luminescence decreases substantially. With Paracetamol, higher concentrations are required for a similar decrease.

\section{Workshops and Teaching Kits for Teachers}

Although a day in the Novartis School Lab might awaken a child's interest in life sciences, whether this enthusiasm lasts, is largely dependent on the teacher's motiva-

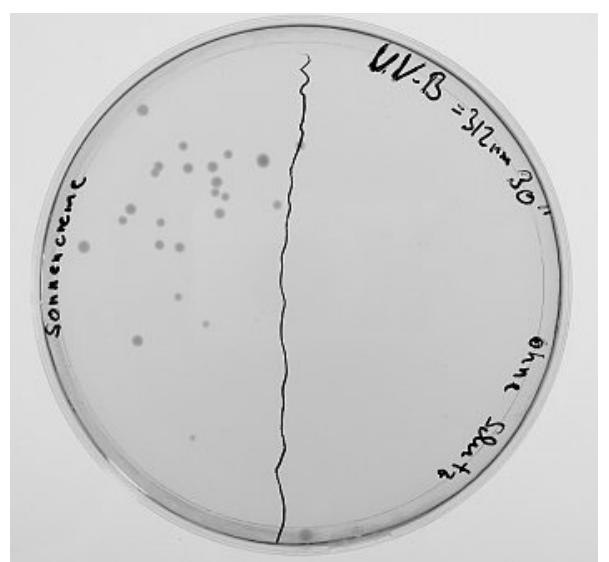

Fig. 7. Effect of UV-light on yeast cells. Left half of the plate was protected by a thin layer of sun cream.

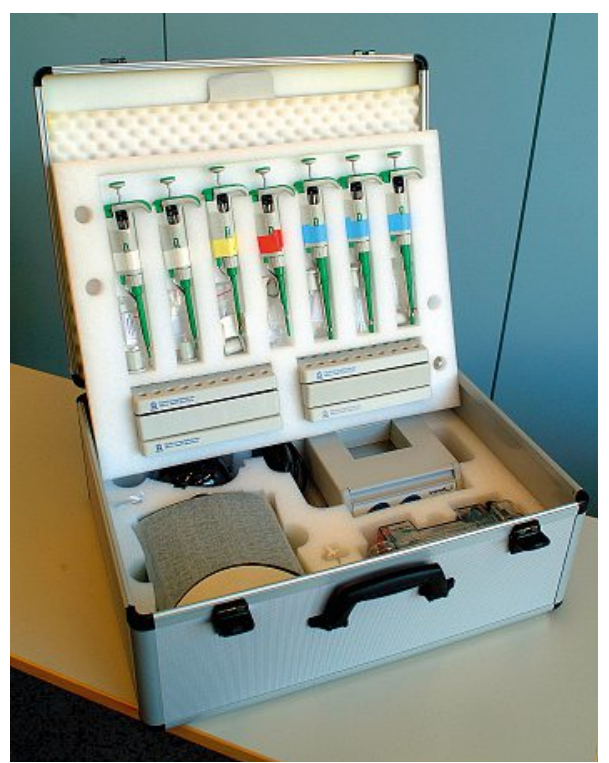

Fig. 8. 'Gen-Spirale' teaching kit. Lent equipment cases include micropipettes, centrifuge, thermo block, electrophoresis chamber and power supply. tion and competence. Therefore the School Lab provides educators with ideas, materials and personal support to develop their practical teaching.

The focus of the teacher workshops is on experiments that work well in the classroom. Here experimental procedures are practiced and teaching strategies are discussed. Besides the regular training courses for the Novartis teaching kits, the School Lab organizes experimental workshops on changing subjects. In a recent workshop the participants studied the effect of UV-light on cell survival and DNA structure and tested the protective effect of their personal sun creams (Figs 6 and 7).

Having the knowledge of experimental science is one thing, possessing the necessary equipment another. Laboratory devices are expensive and chemicals available only in large packs. To facilitate the experimental work in classrooms, the School Lab offers teaching kits comprising equipment, reagents and guidelines for use. The experiments of the teaching kit 'Gen-Spirale' are already an established component in the curriculum of many Swiss high schools. In this program, plasmid DNA is introduced into and multiplied in bacteria cells, then isolated and purified and subjected to restriction analysis. The School Lab lends out the required lab equipment and provides the reagents and consumables (Figs 8 and 9). Since the preparation and carrying out of the experiments can be challenging

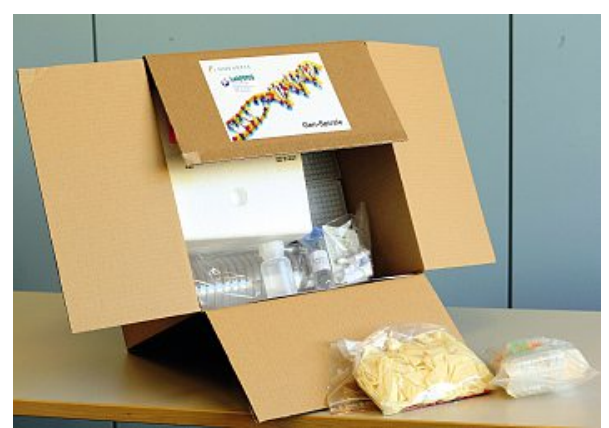

Fig. 9. 'Gen-Spirale' teaching kit. Reagents and consumables are provided. 


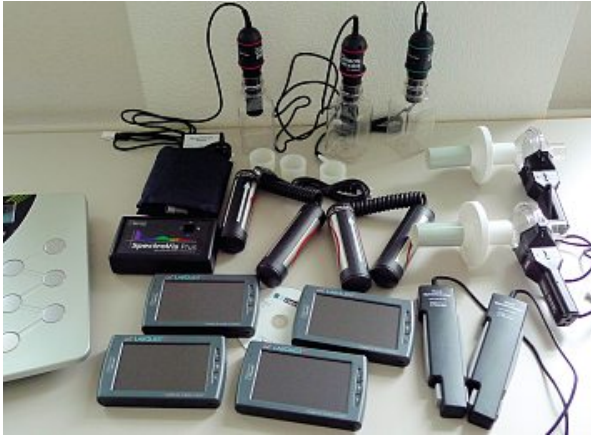

Fig. 10. Tools that will be used in the physiology teaching kit.

for non-scientists and biosafety regulations must be respected when working with genetically modified organisms, teachers are trained in an intensive workshop prior to their first use of the 'Gen-Spirale'. After the experiments are performed at the school, the School Lab team stays in contact with the teachers, answering their questions and giving practical advice.

The creation of an additional teaching kit on physiology is in progress (Fig. 10). Again, this means not only providing equipment and chemicals. Work instructions for experiments on respiration, blood circulation, muscle and nutrition are being developed in cooperation with a group of experienced teachers. Like the training courses for the 'Gen-Spirale', teacher workshops for the physiology kit will be mandatory.

\section{Hands-on Science for the Public}

Novartis School Lab activities are not confined to the laboratories at the Novartis

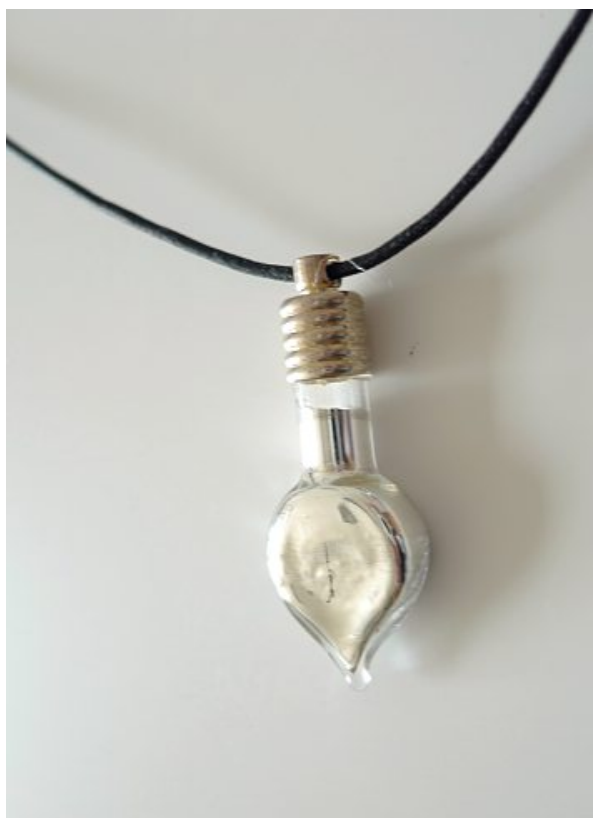

Fig. 12. The desired result: A silver-coated glass heart.

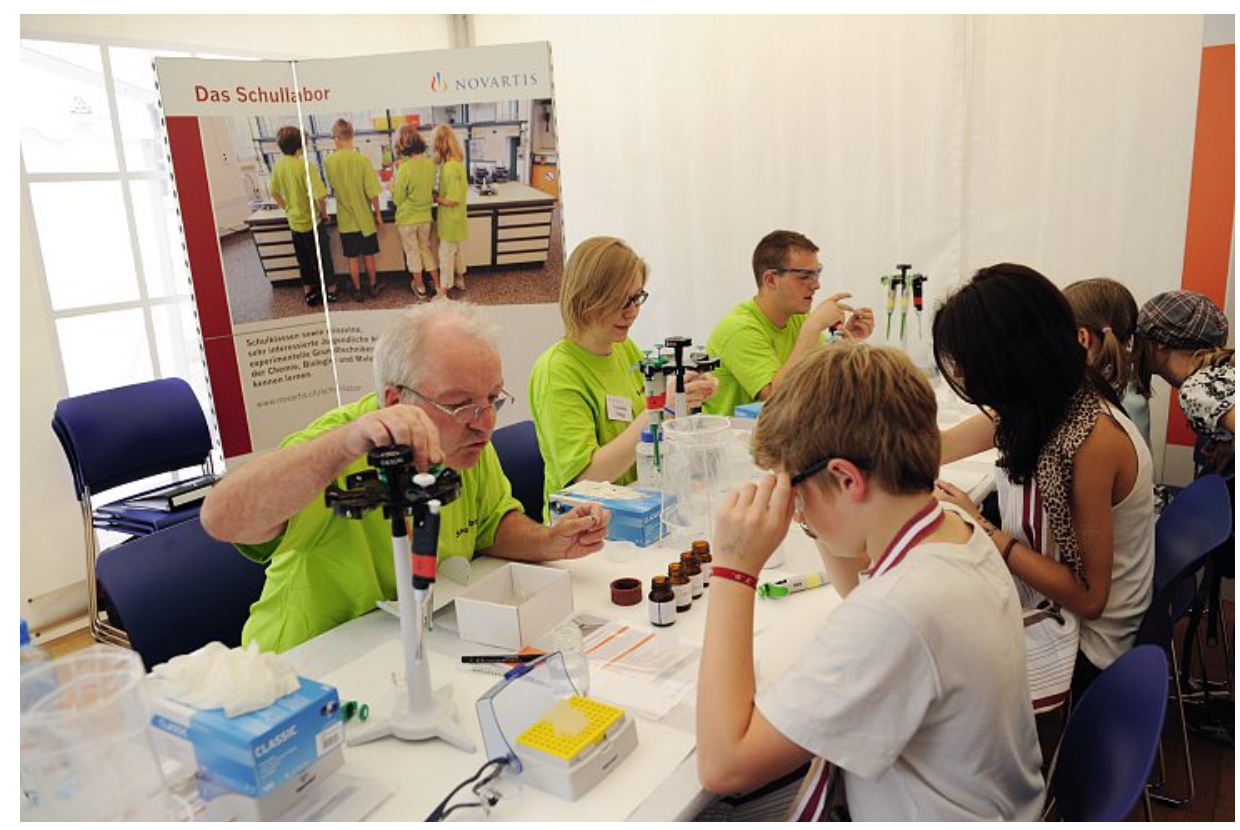

Fig. 11. Fest der Moleküle, 2011. The young visitors were assisted by Novartis apprentices and scientists. site. On a regular basis, the School Lab participates in public science events.

The International Year of Chemistry in 2011 was celebrated with the 'Fest der Moleküle', a two-day event at the University of Basel. With the help of Novartis apprentices, scientists and the School Lab team, young visitors could do hands-on chemistry: the reduction of silver ions to metallic silver (Fig. 11). Since the reaction was performed in a small glass heart-shaped pendant, the metallic silver precipitated as a silver mirror. The children wondered why mixing four colorless liquids (A: $15 \%$ aq. glucose, B: $8 \%$ aq. $\mathrm{AgNO}_{3}, \mathrm{C}: 12 \% \mathrm{NH}_{4} \mathrm{NO}_{3}$ D: $10 \% \mathrm{NaOH}$;
$A: B: C: D=2: 1: 1: 2$ ) would result within minutes in a beautiful silver-heart necklace (Fig. 12). Observing Liebig's silver mirror reaction which first turns to a brownish solution and then changes quickly to the bright silver coating, they experienced that chemistry literally means magic transformation.

The School Lab was also present at the science fair 'tunBasel' which took place during the traditional spring fair (muba). During ten days children, parents and grandparents discovered different fields of hands-on science by constructing, mixing, measuring, tasting, listening and observing. Here the Novartis School

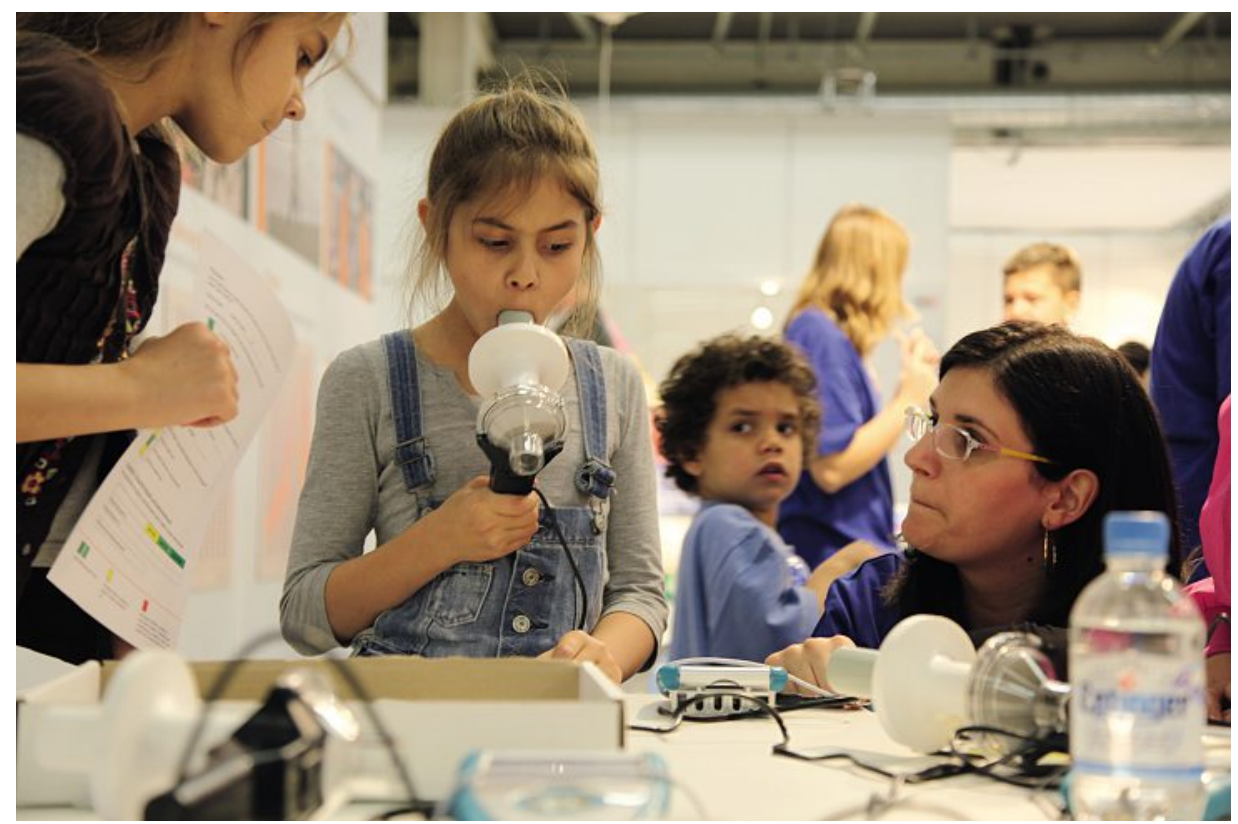

Fig. 13. tunBasel 2012: Be Healthy: Lung function measurements. 


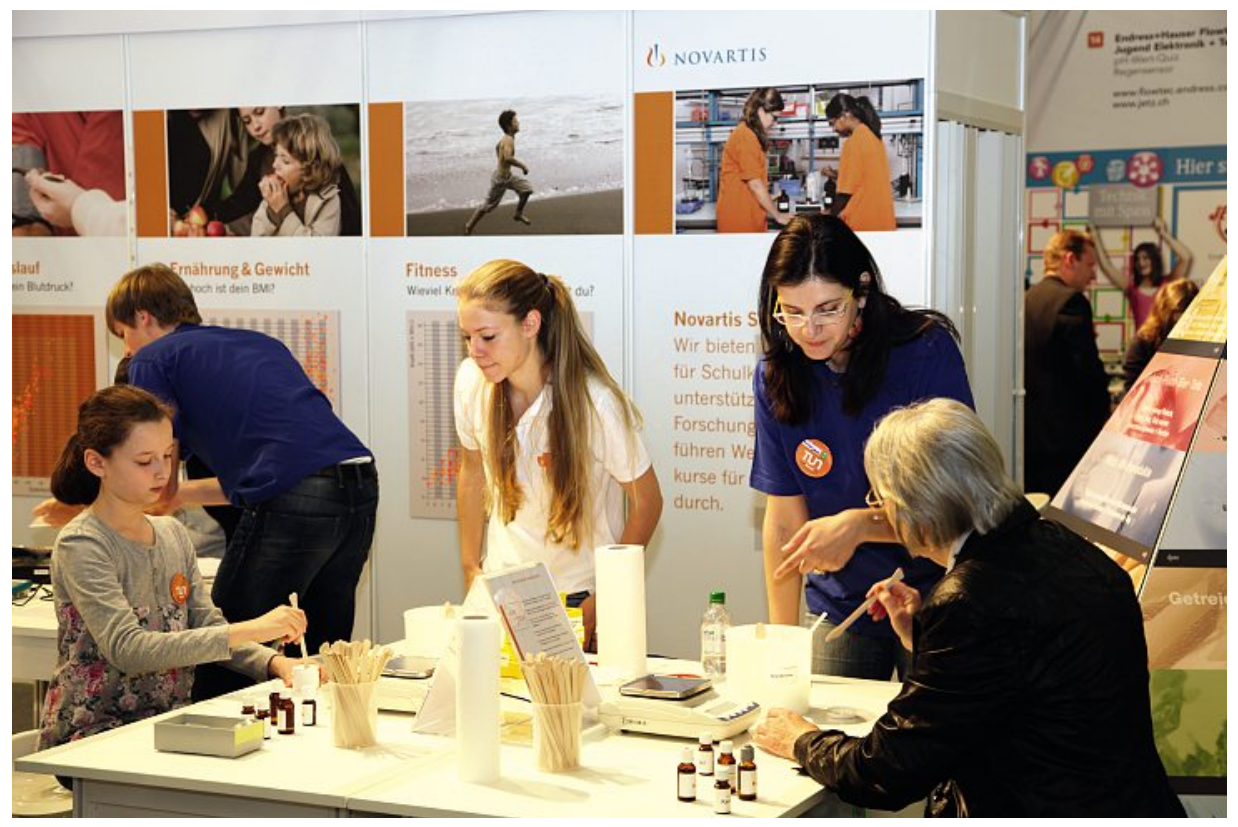

Fig. 14. tunBasel 2012: Preparation of individualized hand cream with preferred fragrance.

Lab operated together with Novartis researchers, students and PhD students from the University of Basel under the title 'Be healthy'. About 5000 visitors measured the capacity of their lungs, their blood pressure and muscle strength and compared their test results with those of other visitors of their age (Figs 13, 14 and 15). Most visitors thoroughly enjoyed the preparation of hand cream with an individual fragrance, an experiment that also illustrated that the biomedical sciences offer a broad spectrum of applications which impact our entire life.

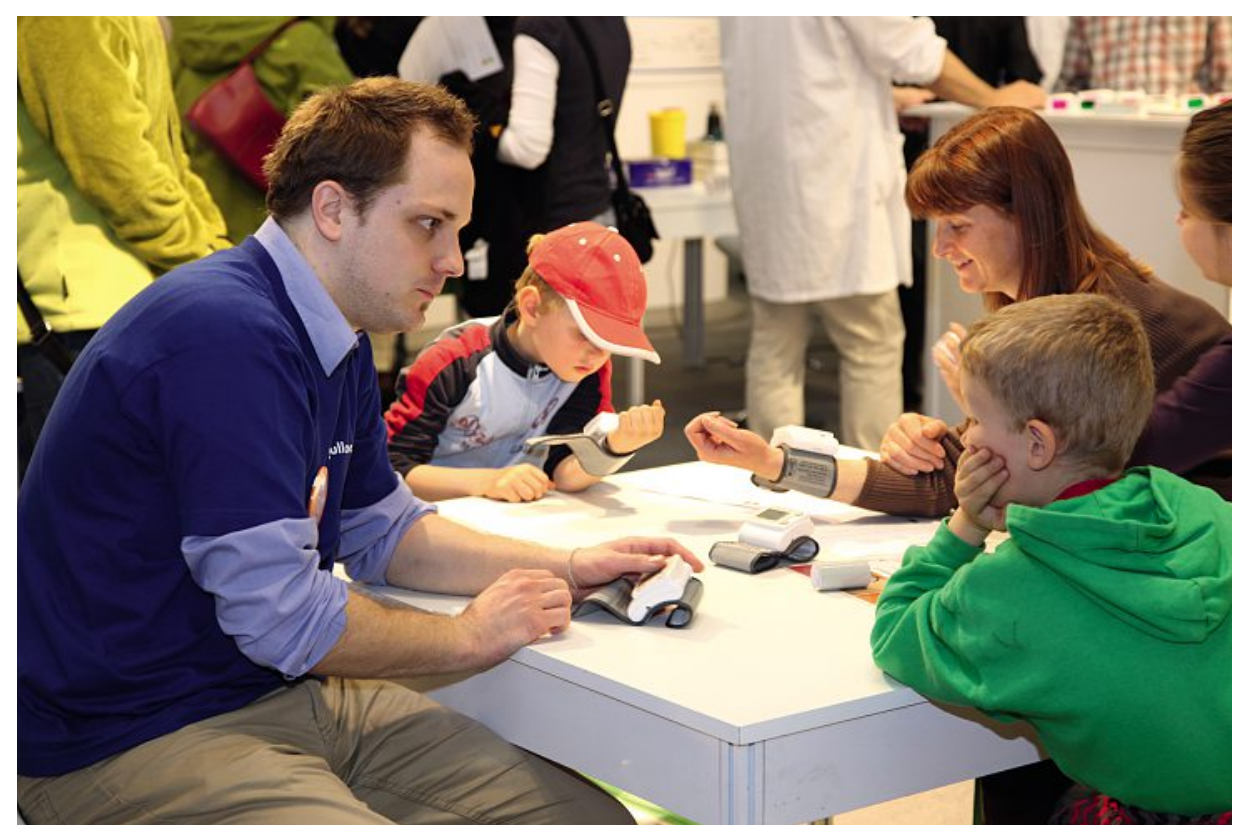

Fig. 15. tunBasel 2012: Be Healthy: Blood pressure measurement and result review. 